Vol. 14 (2005): 293-309.

\title{
Marginal abatement costs for reducing leaching of nitrates in Croatian agriculture
}

\author{
John Sumelius \\ Department of Economics and Management, PO Box 27, FI-00014 University of Helsinki, Finland, \\ e-mail: john.sumelius@helsinki.fi \\ Milan Mesić \\ Department of Agronomy, University of Zagreb, Svetosimunska 25, 1000 Zagreb, Croatia \\ Zoran Grgić \\ Department of Farm Management, University of Zagreb, Svetosimunska 25, 1000 Zagreb, Croatia \\ Ivica Kisic \\ Department of Agronomy, University of Zagreb, Svetosimunska 25, 1000 Zagreb, Croatia \\ Ramona Franić \\ Department of Agricultural Economics and Rural Sociology, University of Zagreb, Svetosimunska 25, \\ 1000 Zagreb, Croatia
}

The aim of this paper is to estimate marginal abatement costs (MAC) of $\mathrm{N}$-fertiliser tax policies which aim to prevent $\mathrm{NO}_{3}$ levels from rising. Estimates of MAC provide information on how large reductions in $\mathrm{N}$ fertilisation rates should be before other measures are considered. Based on $\mathrm{N}$-response experiments from Croatian field trials with maize, $\mathrm{N}$-response curves were estimated and profit maximising $\mathrm{N}$-doses were derived. Values of $\mathrm{NO}_{3}-\mathrm{N}$ concentration in lysimeter water from the same treatments were used to estimate an $\mathrm{NO}_{3}$-leaching function. A sample of 20 Croatian family farms was used to obtain records of producer and input prices as well as actual N-doses. Abatement costs and MAC for an N-tax, a product tax and an Nquota were estimated. The MAC for all the instruments are non-constant and increase at an accelerating rate. The MAC for $\mathrm{N}$-taxes are positive for $\mathrm{N}$-taxes lower than $60 \%$, indicating a net return to society. Reduction rates in fertilisation up to this level should be achieved before considering governmental support for other measures. The N-tax has the lowest abatement cost and the lowest MAC for a particular level of reduction while the N-quota has a lower MAC than the product tax when total reduction levels are below $20 \mathrm{mg} \mathrm{NO}_{3} \mathrm{l}^{-1}$.

Key words: marginal abatement costs, Nitrate Directive, fertiliser taxes, quotas, nitrogen, effluents, maize, agriculture 


\section{Introduction}

Non-point-source pollution involving nitrogen $(\mathrm{N})$ from agriculture is widely recognised to be a major cause of water-quality problems. Excessive levels of $\mathrm{N}$-fertilisation may increase nitrate $\left(\mathrm{NO}_{3}\right)$ leaching. The negative effects of excessive N-leakage are well documented: $\mathrm{N}$ is a plant nutrient which causes eutrophication and, as a consequence, algal bloom and the possible death of fish and other aquatic life. Another principal side effect or externality is rising $\mathrm{NO}_{3}$ levels in drinking water. $\mathrm{N}$, in the form of $\mathrm{NO}_{3}$, is easily soluble and transported in runoff, in tile drainage, and with leachate. In many locations in Europe and North America, excessive $\mathrm{N}$-application may be a cause of water problems (Griffin and Bromley 1982, Andréasson 1990, Hanley 1990, Sumelius 1994, Vatn et al. 1996, 1997, Bleken and Bakken 1997, Jansson 1997, van der Bijl et al. 1999, Granstedt 2000, Shortle et al. 2001).

In the USA, intensification of farming systems through increased nutrient use is one reason for the pollution of surface water and ground water, and for the impairment of water quality (Yadav et al. 1996, Ribaudo 2001, Shortle 1996). In western Europe, there is clear evidence that increased fertiliser use may contribute to the pollution of both surface and groundwaters (Gren et al. 1997, Brouwer and Hellegers 1997, Goodchild 1998, Hanley 2001, De Clerc et al. 2001). Recently, high levels of $\mathrm{NO}_{3}$-leaching from agricultural activities have also been found in some areas of the Central and Eastern European Countries (CEEC), e.g. in Croatia, Poland and Romania. Claims have been made that these $\mathrm{NO}_{3}$-concentrations could be above a safe $\mathrm{NO}_{3}$ level (Tomic et al. 1997, Romic et al. 1997, Klacic et al. 1999, Zellei 2001, Toma 2002, Zellei et al. 2002).

Increased concern that $\mathrm{NO}_{3}$-leaching was becoming a significant problem led to the Nitrate Directive addressed to EU Member States in 1991. The main objective of the Nitrate Directive is to reduce water pollution resulting from or induced by the $\mathrm{NO}_{3}$ that comes from agricultural sources, and to prevent further such pollution. The Nitrate
Directive recognises groundwater containing more than $50 \mathrm{mg} \mathrm{NO}_{3} \mathrm{l}^{-1}$ as being situated in vulnerable zones (Directive 91/676/EEC). This corresponds to $50 \mathrm{mg} \mathrm{l}^{-1} * 0.226=11.3 \mathrm{mg} \mathrm{l}^{-1} \mathrm{NO}_{3}-\mathrm{N}$ (pure $\left.\mathrm{N}\right)$. The conversion factor 0.226 is based on the atomic weights of $\mathrm{N}$ and oxygen $(\mathrm{O})$. In some European countries, stipulation of a maximum amount corresponding to $170 \mathrm{~kg} \mathrm{~N} \mathrm{ha}^{-1}$ that can be spread in the form of manure has been adopted (De Clerck et al. 2001).

One of the general aims of this article is to estimate how $\mathrm{N}$-fertiliser tax policies can prevent $\mathrm{NO}_{3}$ levels from rising in Croatian agricultural systems, and to consider the implications from the viewpoint of farm management. The first specific objective of this study is to determine whether Croatian farmers exceed profit-maximising levels of $\mathrm{N}$-fertiliser use in maize (Zea mays) cultivation. If this is the case, farmers could choose to either reduce fertiliser intensity in order to increase profitability, or search for other critical factors or management practices in the farming system that are limiting their yield levels. Such an adjustment of agricultural practices in maize production would result in the better utilisation of $\mathrm{N}$ and, as a consequence, reduced levels of $\mathrm{NO}_{3}$ in groundwater. On the other hand, if farmers optimise their use of $\mathrm{N}$-fertiliser, there will be a real, farm-level cost associated with this reduced intensity. A second specific objective of this research is to estimate the abatement costs of a given amount of $\mathrm{NO}_{3}$ and the marginal abatement costs (MAC) of reducing $\mathrm{NO}_{3}$-leaching through the use of economic instruments: a tax on $\mathrm{N}$-doses, the use of a product tax or the imposition of a fertiliser quota. The MAC are the marginal change in social costs resulting from a reduction of one $\mathrm{mg} \mathrm{NO}_{3} \mathrm{l}^{-1}$ in the leaching water. The MAC of $\mathrm{N}$-fertiliser tax policies employed to reduce $\mathrm{NO}_{3}$-leaching provide vital information on how large reductions in $\mathrm{N}$ fertilisation rates should be before considering other measures such as catch crops, buffer strips or catchment dams.

Using the theory of externalities, it has been shown that a tax on the externality (i.e. the effluent) represents the optimal first-best solution when markets are competitive and when information is 
Vol. 14 (2005): 293-309.

complete (Baumol and Oates 1988). When the effluent is not observable (which is normally the case in connection with non-point-source pollution) the regulator must use some indirect instruments such as taxes on inputs or the fixing of standards for farming practices (Braden and Segerson 1993). Second-best instruments are the minimisation of costs subject to environmental constraints and subject to the additional restriction of being sub-optimally differentiated across producers. Plausible instruments will necessarily be of a second-best nature (Horan and Shortle 2001). Furthermore, according to Weinberg (1991) effluent taxes may represent an optimal second-best solution in cases where an effluent production function can be estimated with certainty. In practice, due to the nature of non-point source pollution, fertiliser taxes have often been used as a substitute for effluent taxes. A review of experiences with fertiliser taxes in Europe has been published by Rougoor et al. (2001). According to their review, fertiliser taxes in Austria, Finland and Sweden varied between $10 \%$ and $72 \%$ of the price of fertilisers. Price elasticity in these situations was estimated to range between -0.1 and -0.5 .

Some estimates of MAC for fertiliser taxes have been reported. Vatn et al. (1997) found that a $100 \% \mathrm{~N}$-tax leads to a cost for farmers of about NOK 4 per reduced $\mathrm{kg}$ of $\mathrm{N}$-leaching (which equals NOK 17.7 per reduced $\mathrm{kg}$ of $\mathrm{NO}_{3}$-leaching or approximately EUR 2 per reduced $\mathrm{kg}$ of $\mathrm{NO}_{3}$ leaching). The corresponding social MAC per $\mathrm{kg}$ related to reduced leaching of $\mathrm{N}$ (equivalent to the cost to society of a reduction of $1 \mathrm{~kg}$ in N-leaching) were estimated as approximately NOK 20 per additional $\mathrm{kg}$ of $\mathrm{N}$-leakage. These figures are averages from three different study areas in southeastern Norway and varied somewhat depending on the area.

Lankoski and Ollikainen (1999) simulated a $30 \%$ reduction in N-leaching in their study of alternative agri-environmental policy reforms in Finland. They found that a fertiliser tax is less efficient in reducing N-leaching than a buffer-strip subsidy. Depending on the initial situation, the abatement cost of one reduced $\mathrm{kg}$ of $\mathrm{N}$ was FIM 24.7 (EUR 4.15) for a fertilizer tax and an acreage subsidy, FIM 40.7 (EUR 6.85) for a reduced price support and a buffer zone subsidy and FIM 30.7 (EUR 5.16) for a fertiliser tax combined with a buffer zone subsidy. Lankoski (2000) also concluded that an agri-environmental policy mix which compensates for the increase in fertiliser tax through a higher buffer-strip subsidy had a stronger reductive effect on nutrient runoff than either a fertiliser tax or a buffer-strip subsidy when used alone. Similar results were reported by Lankoski (2003). The studies by Lankoski were not based on measured N-leaching, but on a Danish leaching function estimated by Simmelsgaard (1991).

This paper introduces a new contribution in that it reports the influence of $\mathrm{N}$-taxes, $\mathrm{N}$-quotas or product taxes on $\mathrm{NO}_{3}$-leaching in one CEEC, Croatia, based on data from empirical experiments on $\mathrm{N}$-response and $\mathrm{NO}_{3}$-leaching from the same experimental plots. The results from experimental conditions are calibrated against results from an on-farm survey of 20 family farms carried out in 1999 and 2000 (Grgić and Mesić 2001). The paper is organised in the following way. Profit-maximising $\mathrm{N}$-doses on the basis of field experiments (56 observations) with maize are determined based on first- and second-order conditions for profit maximisation. This profit-maximising $\mathrm{N}$-dose is then compared against actual $\mathrm{N}$-fertiliser use on the farms surveyed to see whether profit-maximising levels were exceeded or not. The effects of a change in fertiliser intensity on the leaching of $\mathrm{NO}_{3}$ is then established. In order to do this, an effluent production function is estimated based upon the $\mathrm{N}$-concentration in lysimeter water for the same treatment levels and soils as the N-response. The effects on $\mathrm{NO}_{3}$-leaching resulting from a change in profit-maximising fertiliser intensity are then approximated by employing this effluent production function. The cost to farmers of implementing a $50 \%$ fertiliser tax, a $100 \%$ product tax and a quota that corresponds to these taxes are then calculated. Next, the full social cost and the marginal costs of abatement are calculated. Finally, conclusions are drawn and recommendations for Croatian agriculture are made which would, if implemented, reduce the threat of rising $\mathrm{NO}_{3}$ levels in groundwater. 


\section{Model}

Doses of crop nutrients, especially the pure Ndose, have a major effect on both production and economic results as they affect maize and wheat production. In cases where a farmer uses excessive levels of N-fertilisers, such excessive use will result in both additional economic cost to him and the likelihood that $\mathrm{N}$-leaching will increase. We therefore assume that the experimental conditions can be considered as a "suggested method of production".

Although it is customary to assume that farmers are profit-maximizers, the optimising behaviour of farmers is subject to debate. Some evidence exists that farmers actually minimize costs rather than maximize profits (Tauer 1995). It is also clear that expected profit maximization by firms is far from trivial (Gabel and Sinclair-Desgagné 2001). In spite of this debate, for simplicity we have assumed that farmers maximize expected profits. Nfertiliser is the only input to be considered in the profit function and it is assumed that $\mathrm{N}$-fertilisation only affects returns through higher yields, not through protein content. The farmer's profit function can be written as a short-term profit function (e.g. Varian 1992):

$$
\begin{aligned}
\pi(p, w) & =\underset{\mathrm{x} \geq 0}{\operatorname{Max}} \pi(p f(x)-w x) \\
\text { where } & \pi=\text { profit } \\
p & =\text { price of } \mathrm{y} \\
y & =f(x)=\text { production function } \\
x & =\text { quantity of } \mathrm{N}-\text { fertilisers applied } \\
w & =\text { price of } \mathrm{N}-\text { fertiliser input }
\end{aligned}
$$

The profit function $\pi(p, w)$ in (1) is the indirect objective function of the farmer. Its value is always the maximum value of profits given $w$ and $p$, when profit-maximising levels of input $x^{*}$ have been substituted back into the profit function.

Assume a financial incentive or economic instrument, denoted $k$, corresponding to: $\mathrm{A}$ (an Nfertiliser tax); B (a product tax); or C (a non-uniform fertiliser quota). If $k$ is an $\mathrm{N}$-fertiliser tax $k_{f t}$, rewriting (1) and taking the first-order conditions for profit maximisation gives

$$
f^{\prime}(x)=\frac{w\left(1+k_{f t}\right)}{p} .
$$

Correspondingly, if $k$ is a product tax $k_{p t}$, taking first-order conditions gives

$$
f^{\prime}(x)=\frac{w}{p\left(1-k_{p t}\right)} .
$$

Finally, if $k$ is a quota, (1) should be written as

$$
\pi(p, w)=p f(\bar{x})-w \bar{x} .
$$

and the optimisation problem for the farmer can be stated as a constrained maximisation problem, i.e. to maximise the Lagrangian:

$$
L=p f(x)-w x+\lambda(\bar{x}-x)
$$

subject to:

$$
\begin{aligned}
& \frac{\partial L}{\partial x}=p f^{\prime}(x)-w-\lambda=0 \\
& f^{\prime}(x)=\frac{w+\lambda}{p} .
\end{aligned}
$$

In other words, comparing the instruments $\mathrm{A}$, $\mathrm{B}$, and $\mathrm{C}$ is equivalent to comparing (2), (3), and (5) in a situation where $w+k_{f t}=p-k_{p t}=\lambda$. We denote $w_{1}^{k}$ as $\left(w+k_{f t}\right)$ and $p_{1}^{k}$ as $\left(p-k_{p t}\right)$. Profitmaximising input levels will adjust to a new level $x^{f *}=x\left(p, w_{1}^{k}\right)$ in the case of fertiliser taxes, and to $x^{p *}=x\left(p_{1}^{k}, w\right)$ in the case of product taxes. By setting equation (2) equal to equation (3) one obtains the equivalence between fertiliser tax and the product price, i.e

$$
k_{p t}=\frac{k_{f t}}{1+k_{f t}} .
$$

Modifying work by Shortle and Abler (1997) and Horan and Shortle (2001), the ambient concentration for non-point-source pollution can be written as:

$$
a=a(r, b, v, q)
$$

where $a$ is the ambient concentration $\left(\mathrm{NO}_{3}\right.$-concentration), $r$ is a vector representing leaching from non-point-sources, $b$ is natural generation of the pollutant, $v$ is precipitation and $q$ is a vector of watershed characteristics. Effluent production $\left(\mathrm{NO}_{3}\right.$-leaching) is given by: 
Vol. 14 (2005): 293-309.

$$
r=g(x, v, s)
$$

where $x$ represents the quantity of fertiliser as stated before and $s$ is soil type.

Since the financial incentive $k$ only affects effluents, its effect on ambient concentration is given by

$$
\frac{d a}{d k}=\frac{\partial a \partial r}{\partial r} \partial k
$$

where $d$ denotes the total derivative and $\partial$ denotes a partial derivative.

The effect of an $\mathrm{N}$-taxes or producer tax on ambient concentration will be:

$$
\frac{d a}{d k}=\frac{\partial g(x(p, w, k), v, s)}{\partial k} .
$$

Given that environmental consequences (both physical and economic) depend on the ambient concentration, the economic cost of damage from non-point-sources is given by $D(a)$. It is a function that increases at a growing rate with increasing levels of the ambient pollutant.

The abatement cost is a social cost per unit of abatement. The MAC are the marginal social cost per unit of marginal abatement. The social cost can be thought of as the reduction in net income for farmers which has been adjusted by removing the cost influence of taxes arising from the financial incentive $k$ (in principle, the taxes could be paid back to farmers in the form of direct subsidies or agri-environmental payments). A similar measure was used by Vatn et al. (1997). The MAC for the economic instrument $k$ will be:

$$
M A C=\frac{\partial \sum_{i=1}^{m} \pi_{i}(p, w, k) / \partial k}{\partial r / \partial k}
$$

Put more simply, the MAC for reducing leaching by applying the financial-tax-policy incentive $k$ are equal to the relationship between the marginal social cost and the reduced amount of leaching. A lump sum tax could be considered as representing transaction costs arising from the tax scheme. A lump sum tax does not however affect the MAC.

$r=g(x, v, s)$ increases at an accelerating rate with respect to $x$ (i.e. $r^{\prime}>0, r^{\prime \prime}>0$ ) except for very low values of $x$. MAC are therefore non-constant, suggesting that small reductions in $x$ result in low MAC, while large reductions give higher MAC.

A cost-efficient policy is one where the MAC for different measures, evaluated at their optimum should be equal. Hence, MAC provide information on how large reductions in fertilisation rates should be before other measures (like support for catch crops, catchment dams or buffer strips) should be considered.

In order to estimate (9), assumptions concerning the forms of the production functions and the effluent-production function must be made. Polynomial forms of the production functions (quadratic and square root) have often been assumed when describing the N-response (e.g. by Heady and Dillon 1961, Laurila 1992, Bakken and Romstad 1992). Paris (1992) suggested the Mitscherlich function as the appropriate functional form of the N-response. In the present study, quadratic, square-root and Mitscherlich functions were all initially assumed. A comparison between the polynomial and Mitscherlich functional forms of the $\mathrm{N}$-response has also been made in a number of other studies (Sumelius 1993, Bäckman et al. 1997). The three forms of the production function and corresponding first-order conditions (FOC) are presented in Table 3. For all of them, $y^{\prime}>0$, $y^{\prime \prime}<0$, i.e. they are characterised by the law of diminishing returns.

The effluent production function in (7) will influence the MAC in (9). How can an appropriate form of the effluent-production function (i.e. an $\mathrm{NO}_{3}$-leakage function) be selected? As already noted, it might be thought that $\mathrm{NO}_{3}$-leaching is an increasing function that is related to increasing $\mathrm{N}$ input levels $(x)$ in grain production. As pointed out by Vatn et al. (1996), the $\mathrm{NO}_{3}$-leaching function initially decreases for very low levels of $\mathrm{N}$ (lower than $3 \mathrm{~g} \mathrm{Nm}^{-2}$ ). The explanation for this is that if yield growth is low because of low $\mathrm{N}$-input, this prevents nutrient uptake. Vatn et al. also note that this reduction may be of nothing more than academic interest, since grain cropping without fertilisers is relatively rare. At levels above $6 \mathrm{~g} \mathrm{Nm}^{-2}$, $\mathrm{NO}_{3}$-leaching is seen to rise substantially with increasing $\mathrm{N}$-levels, with a positive second deriva- 
tive $\left(r^{\prime \prime}>0\right)$. This is the starting point for selecting the functional form of the effluent-production function.

Several sophisticated simulation models for describing $\mathrm{NO}_{3}$-leaching now exist. This raises the issue of using simulation models instead of an effluent-production function approach. In an article developing an empirical model for the estimation of $\mathrm{NO}_{3}$-leaching, Simmelsgaard and Djurhuus (1998) develop an empirical model for the estimation of $\mathrm{NO}_{3}$-leaching. They provide a good argument for using leaching functions based on lesscomplicated models which rely on the use of regression analysis. In many cases, they argue, the more complex models are of limited use because of their data requirements concerning climate and the chemical and physical properties of the soil. Such models are therefore best employed for research and in specific areas where the data requirements can be fulfilled. In situations where actual empirical data on $\mathrm{NO}_{3}$-leaching exists, it may be sufficient to assume a simple form of effluent-production function and then to estimate this. Simmelsgaard and Djurhuus propose a simple empirical model which incorporates only the short-term effects of an N-fertiliser rate and is based on relatively-small quantities of data on $\mathrm{NO}_{3}$-leaching. The model proposed by Simmelsgaard and Djurhuus is for use in situations where existing data on $\mathrm{NO}_{3}$-leaching is lacking, and in situations when expected values of $\mathrm{NO}_{3}$-leaching cannot be calculated by using other models. The two basic models are based on a logarithmic regression in which $\mathrm{NO}_{3}$-leaching is the dependent variable:

$$
\begin{aligned}
& \ln \left(r_{\text {crop,year(crop),location }}\right)= \\
& \alpha+\alpha_{1} N_{\text {crop,year (crop),location }}+\varepsilon_{\text {crop,year (crop),location }}
\end{aligned}
$$

or:

$$
\begin{aligned}
& \ln \left(r_{\text {crop,year(crop),location }}\right)=\beta+\beta_{1} N_{\text {crop,year(crop),location }} \\
& +\beta_{1} N_{\text {crop,year(crop),location }}^{r}+\beta_{2} \ln \left(\frac{D_{a}}{D_{\text {norm }}}\right) \\
& +\varepsilon_{\text {crop,year(crop),location }}
\end{aligned}
$$

$N^{r}=$ actual $\mathrm{N}$-fertilisation divided economically-optical $\mathrm{N}$-fertilisation $(1 N)$

$D_{a}=$ drainage from the root zone, $\mathrm{mm}$ year ${ }^{-1}$

$D_{\text {norm }}=$ average normal drainage from the root zone, mm year $^{-1}$

$\alpha_{i}, \beta_{i}=$ the coefficient ts to be estimated

According to Simmelsgaard and Djurhuus, the logarithmic transformation was used to obtain constant variance and would therefore seem to have been applied because of problems with data. Furthermore, it was noted that the $\mathrm{NO}_{3}$-leaching function decreases at very low levels of N. Consequently, a square-root functional form would be better able to capture this fact than model (10) or (11). For this reason, a model according to (12):

$$
\begin{aligned}
& r_{\text {crop,year(crop),location }}=\beta+\beta_{1} \sqrt{N_{\text {crop,year(crop),location }}}+ \\
& \beta_{2} N_{\text {crop,year(crop),location }}+\delta_{1} D_{1}+\delta_{2} D_{2}+\delta_{3} D_{3}+ \\
& \varepsilon_{\text {crop,year(crop),location }}
\end{aligned}
$$

where

$$
\begin{aligned}
& r=\mathrm{NO}_{3}-\mathrm{N}, \mathrm{mg} \mathrm{l}^{-1} \\
& N=\mathrm{N} \text {-fertilisation, } \mathrm{kg} \mathrm{ha}^{-1} \\
& D_{1}-D_{3}=\text { dummies for year (4 years) } \\
& \beta_{i}, \delta_{i}=\text { coefficients to be estimated }
\end{aligned}
$$

was assumed in this study (observe that $r$ is measured as a concentration of $\mathrm{NO}_{3}-\mathrm{N}$ ). The $\mathrm{NO}_{3}-\mathrm{N}$ leaching and $\mathrm{N}$-response functions will be substituted back into (7) and (9) to find the MAC. Annual dummies were included to take account of yearly variation. If the $\delta_{i}$-coefficients equal zero, the correct model will be the restricted model (13):

$$
\begin{aligned}
& r_{\text {crop,year(crop),location }}=\beta+\beta_{1} \sqrt{N_{\text {crop,year(crop),location }}}+ \\
& \beta_{2} N_{\text {crop,year(crop),location }}+\varepsilon_{\text {crop,year(crop),location }}
\end{aligned}
$$

It is possible to test the null hypothesis that $\delta_{1}$ $=\delta_{2}=\delta_{3}=0$ in the unrestricted model (12) using an F-test or likelihood-ratio test. 
Vol. 14 (2005): 293-309.

\section{Material and methods}

\section{Field trial}

With the aim of determining sustainable mineral $\mathrm{N}$-rates for the fertilisation of major field crops in central Croatia, a stationary field trial with 10 treatments in four replications was set up in the Lonja Field (Lonjsko polje) near Popovaca. In the first (1996) and fourth investigation years (1999), maize was grown as a test crop on the trial area. Water leached through the soil to a depth of $80 \mathrm{~cm}$ was caught by installed lysimeters without lateral sides (after Ebermayer). The trial included ten treatments, but only seven are taken into consideration in this analysis: 1. Check, 2. $\mathrm{N}_{0} \mathrm{PK}, 3 . \mathrm{N}_{100} \mathrm{PK}, 4$. $\mathrm{N}_{150} \mathrm{PK}, 5 . \mathrm{N}_{200} \mathrm{PK}, 6 . \mathrm{N}_{250} \mathrm{PK}, 7 . \mathrm{N}_{300} \mathrm{PK}$. The trial plot size was $30 \times 130 \mathrm{~m}\left(3900 \mathrm{~m}^{2}\right)$. The omitted trial treatments included: $1 . \mathrm{N}_{250} \mathrm{PK}+$ phosphogypsum (12 $\left.\mathrm{t} \mathrm{ha}^{-1}\right) ; 2 . \mathrm{N}_{250} \mathrm{PK}+$ zeolite $+\mathrm{CaCO}_{3}(3 \mathrm{t}$ $\left.\mathrm{ha}^{-1}\right)$; and 3. Black fallow. The reason for omitting these trials was that they could not be included in a production function which describes only the influence on N. Fertilization of the maize crop was carried out with $600 \mathrm{~kg} \mathrm{ha}^{-1}$ of NPK 7-20-30, which amounted to $42 \mathrm{~kg} \mathrm{~N}, 120 \mathrm{~kg}$ phosphorus (P) and $180 \mathrm{~kg}$ potassium $(\mathrm{K})$. In the $\mathrm{N}_{0} \mathrm{PK}$ treatment, mineral fertilizers without $\mathrm{N}$ were applied. Of the total $\mathrm{N}$-quantity, $60 \%$ was applied before planting and the remaining $40 \%$ was applied in two top dressings, each of which was $20 \%$ of the total N-quantity. Maize was sown on 18 May 1996. (hybrid ETA 272 , population density 77,000 plants $\mathrm{ha}^{-1}$ ) and on 8 May 1999 (hybrid Bc 318, population density 69,000 plants $\mathrm{ha}^{-1}$ ). The $\mathrm{N}$-content was determined in soil samples, in lysimeter water and in plant material. The total number of observations was thus based on four replications, seven treatments and two years, which gives $n=56$.

\section{Soil properties}

The soil type at the experimental station is defined as Stagnosol (ISSS 1994), with an $\mathrm{A}_{\mathrm{ch}}+\mathrm{E}_{\mathrm{cg}}-\mathrm{E}_{\mathrm{cg}}$ $-\mathrm{B}_{\mathrm{tg}}$ sequence of soil horizons. Its physical properties (high content of fine sand, silt and clay) and chemical properties (calcium deficiency, low content of organic matter) mean that this soil is of a type that has limited fertility. Intensive mineral fertilisation is very important for stable arable farming in the given conditions. The soil is loam in the $\mathrm{A}$ and $\mathrm{E}$ horizons, and sandy clay loam in the $\mathrm{B}$ horizon. Soil reaction is acid in the topsoil and slightly acid in the $\mathrm{B}_{\mathrm{tg}}$ layer. There is low humus and medium $\mathrm{N}$-content in the plough layer. The soil-supply of plant-available P is good, and the soil-supply of plant-available $\mathrm{K}$ is medium.

The $\mathrm{NO}_{3}-\mathrm{N}$ concentration in lysimeter water varied in accordance with the application time of mineral N-fertilizers, with temperature, and especially with the quantity and intensity of precipitation. Values for the $\mathrm{NO}_{3}-\mathrm{N}$ concentration in lysimeter water and the quantity of water in the lysimeter were used to calculate the total $\mathrm{NO}_{3}-\mathrm{N}$ loss. The total number of observations was 40 . Results based on leaching data for $\mathrm{NO}_{3}-\mathrm{N}$ were converted to $\mathrm{NO}_{3}$-values after estimation.

\section{Farm survey and area}

The area in Croatia where the sample of 20 farms is located is situated close to Lonja field (Lonjsko polje), which covers some 50,600 hectares of forest, pastures and meadows. Lonjsko polje Nature Park is the second-largest protected area in Croatia. Because of the high levels of biodiversity, there are many reasons for conservation activities in this area. The climate of Lonja field is typically continental. Major long-term (1965-1990) indicators of climatic conditions in the course of the investigation are shown in Table 1. It is worth noting that mean long-term precipitation totals $865 \mathrm{~mm}$. The average temperature is $10.7^{\circ} \mathrm{C}$.

Approximately 1600 family farms with an average of 3.3 hectares of agricultural land are engaged in agricultural production in this area. Only $10 \%$ of farmers own more than 7.5 hectares of land. Farms currently receive subsidies based on the area they cultivate. No cross-compliance between agronomic practices and acreage subsidies exist. Only a few of the farms have a high level of technology (Grgic and Mesić 2001). 
Sumelius, J. et al. Marginal abatement costs for reducing leaching of nitrates in agriculture

Table 1. Precipitation and average air temperature during the period of investigation.

\begin{tabular}{|c|c|c|c|c|c|c|c|c|c|c|c|c|c|c|}
\hline \multirow{2}{*}{ Year } & & \multicolumn{12}{|c|}{ Total monthly precipitation $(\mathrm{mm})$ and average air temperature $\left({ }^{\circ} \mathrm{C}\right)$} & \multirow{2}{*}{ Year } \\
\hline & & I & II & III & IV & $\mathrm{V}$ & VI & VII & VIII & IX & $\mathrm{X}$ & XI & XII & \\
\hline \multirow{2}{*}{1996} & $\mathrm{~mm}$ & 54 & 32 & 41 & 70 & 71 & 31 & 91 & 83 & 191 & 46 & 135 & 79 & 922 \\
\hline & ${ }^{\circ} \mathrm{C}$ & -0.6 & -0.8 & 3.4 & 10.8 & 17.4 & 20.7 & 19.8 & 20.5 & 13.5 & 12.0 & 8.7 & -1.4 & 10.3 \\
\hline \multirow{2}{*}{1999} & $\mathrm{~mm}$ & 42 & 63 & 38 & 126 & 107 & 89 & 86 & 66 & 95 & 73 & 92 & 104 & 980 \\
\hline & ${ }^{\circ} \mathrm{C}$ & 1.2 & 2.4 & 9.1 & 12.6 & 17.2 & 20.2 & 21.9 & 21.2 & 18.6 & 11.6 & 3.6 & 1.9 & 11.8 \\
\hline \multirow{2}{*}{ 1965-1990 } & $\mathrm{mm}$ & 53 & 51 & 59 & 73 & 80 & 90 & 77 & 85 & 80 & 63 & 87 & 65 & 865 \\
\hline & ${ }^{\circ} \mathrm{C}$ & -0.2 & 2.0 & 6.6 & 11.0 & 15.9 & 19.0 & 20.8 & 19.8 & 16.1 & 10.8 & 5.3 & 1.4 & 10.7 \\
\hline
\end{tabular}

The most important crops in the area are maize, winter wheat, red clover, and in some cases alfalfa. Despite the relatively-high doses of $\mathrm{N}$-fertilisation, average yields for crops are low, particularly as regards winter wheat and maize. Because of the very complex conditions existing in Croatian agriculture today, farmers desire higher yields, but their knowledge concerning many important issues related to soil tillage, mineral and organic fertilisation, and the general improvement of soil fertility, can at best be described as "problematic". In most cases, it is possible to speak about a remarkably-narrow crop rotation, since maize and winter wheat are the most important crops. The relationship between fields under these two crops indicates that maize is often grown in short-term monoculture.

For the purposes of this study, we selected 20 family farms as the targets for a survey concerning their capacities. The farms are typical as regards agricultural production in the region: 3-10 hectares of maize and wheat production. The total seeded area of self-owned and rented land varied between 11 and 25 hectares, on average it was 16 hectares. All of the farms had livestock, either dairy or beef cattle or pigs. To make the sample representative of the distribution of all farms in the area we used the following criteria for selecting sample farms: size of cultivated area, number of household members, crops cultivated, technology of production, yield level and inclusion in the system of production supported by the Ministry of Agriculture.

As regards the surveyed farms, nutrient balances at farm level were calculated for all 20 farms based upon production results for the years 1999 and 2000. $\mathrm{N}$-input in the form of artificial fertilisers was calcu- lated and the prices paid for these fertilisers were collected. All prices are expressed in terms of values in October 2000 using an exchange rate of EUR $1=$ KUN 7.60. The average prices obtained were, for maize KUN $0.75 \mathrm{~kg}^{-1}$ (EUR $0.0987 \mathrm{~kg}^{-1}$ ) and for wheat KUN $1.05 \mathrm{~kg}^{-1}$ (EUR $0.138 \mathrm{~kg}^{-1}$ ). In addition to sales revenue, the producers received an areabased subsidy equalling KUN $700 \mathrm{ha}^{-1}$ in maize production and KUN $1050 \mathrm{ha}^{-1}$ in wheat production. Maize yields on the 20 surveyed farms were in the range 5130 to $6270 \mathrm{~kg} \mathrm{ha}^{-1}$, and wheat yields ranged from 4218 to $5130 \mathrm{~kg} \mathrm{ha}^{-1}$. In maize production, the 20 farms used 206-230 kg ha-1 of pure $\mathrm{N}$ including manure. In wheat production they used $234-236 \mathrm{~kg}$ $\mathrm{ha}^{-1}$ of pure $\mathrm{N}$ including manure.

\section{Results and discussion}

\section{$\mathrm{N}$-response for maize}

Based on the field trials described earlier, the production function (N-response) of maize was estimated using Ordinary Least Squares (OLS) (quadratic and square-root forms) and Non-Linear Least Squares (Mitscherlich form) using the Eviews software program Version 3.1. The results for the various specifications are presented as the response functions $\mathrm{N}$-fertiliser-yield shown in Table 2.

There is no evidence that the central assumptions behind OLS would not be in accordance with the estimated results. All in all, the polynomial forms for estimating $\mathrm{N}$-response for maize appear to work out well. All three functional forms seem 
Vol. 14 (2005): 293-309.

Table 2. Results for Ordinary Least Squares and Non-linear Least Squares estimations of maize nitrogen response $(\mathrm{n}=56)$ and the $\mathrm{NO}_{3}-\mathrm{N}$ leaching function $(\mathrm{n}=40)$.

\begin{tabular}{|c|c|c|c|}
\hline Variable & Coefficient $^{1)}$ & t-statistic & Probability \\
\hline \multicolumn{4}{|l|}{ Quadratic function } \\
\hline$\beta_{0}$ & $\begin{array}{l}54.9450 \\
(3.2033)\end{array}$ & 17.153 & 0.0000 \\
\hline$\beta_{1}$ & $\begin{array}{c}0.2914 \\
(0.0539)\end{array}$ & 5.411 & 0.0000 \\
\hline$\beta_{2}$ & $\begin{array}{c}-0.0005 \\
(0.0002)\end{array}$ & -2.775 & 0.0076 \\
\hline $\bar{R}^{2}$ & 0.6247 & & \\
\hline White heteroscedasticty test: F-stat & 0.3474 & & \\
\hline \multicolumn{4}{|l|}{ Square root function } \\
\hline$\beta_{0}$ & $\begin{array}{c}55.0666 \\
(3.2931)\end{array}$ & 16.722 & 0.0000 \\
\hline$\beta_{1}$ & $\begin{array}{c}2.6256 \\
(1.0619)\end{array}$ & 2.4724 & 0.0167 \\
\hline$\beta_{2}$ & $\begin{array}{c}-0.0073 \\
(0.0652)\end{array}$ & -0.112 & 0.9110 \\
\hline $\bar{R}^{2}$ & 0.6146 & & \\
\hline White heteroscedasticty test: F-stat & 0.2622 & & \\
\hline \multicolumn{4}{|l|}{ Mitscherlich function } \\
\hline$M$ & $\begin{array}{r}103.3900 \\
(9.9061)\end{array}$ & 10.437 & 0.0000 \\
\hline$K$ & $\begin{array}{c}0.4680 \\
(0.0558)\end{array}$ & 8.389 & 0.0000 \\
\hline$\beta$ & $\begin{array}{c}-0.0071 \\
(0.0034)\end{array}$ & 2.100 & 0.0405 \\
\hline $\bar{R}^{2}$ & 0.6213 & & \\
\hline White heteroscedasticty test: F-stat & 0.4953 & & \\
\hline \multicolumn{4}{|c|}{ Leaching function (Effluent-production function) } \\
\hline$\alpha_{0}$ & $\begin{array}{c}6.396 \\
(1.835)\end{array}$ & 3.486 & 0.0013 \\
\hline$\beta_{1}$ & $\begin{array}{c}-2.124 \\
(0.692)\end{array}$ & -3.071 & 0.0040 \\
\hline$\beta_{2}$ & $\begin{array}{c}0.207 \\
(0.043)\end{array}$ & 4.834 & 0.0000 \\
\hline $\bar{R}^{2}$ & 0.680 & & \\
\hline
\end{tabular}

1) Standard error in parenthesis.

to describe the $\mathrm{N}$-response for maize in a satisfactory manner, and the goodness of fit is almost identical. The response functions estimated by OLS for maize appear satisfactory. Estimating the Mitscherlich functions with non-linear least squares also gave satisfactory results with respect to heteroscedasticity. The final criterion for choosing the Mitscherlich functional form is based on a theo- retical viewpoint. It has been shown that this functional form accords best with the von Liebig hypothesis known as the "Law of the Minimum" (Paris 1992a, b, Sumelius 1993)․․

\footnotetext{
${ }^{1}$ It should be noted that in the final estimates of MAC, the selection of functional form had only a minor influence.
} 
It may be added that initially, a data set for wheat similar to that of maize was used to estimate $\mathrm{N}$-response functions but heteroscedasticity was found to be a problem. It was therefore decided that the winter wheat response function should be excluded from our analysis. The results obtained based on these excluded functions were similar to the results presented here.

\section{Profit-maximising $\mathrm{N}$-fertiliser level}

Optimal N-fertiliser levels for profit maximisation in maize cultivation stipulated by the first-order conditions of profit maximisation for the Mitscherlich specification are presented in Table 3.

Profit-maximizing levels for the quadratic and square-root forms are also presented in this table. The prices for $\mathrm{N}$-fertiliser used in the calculation, in maize production KUN $7.62(\mathrm{~kg} \mathrm{~N})^{-1}$ (EUR $1.00(\mathrm{~kg}$ $\mathrm{N})^{-1}$ ), were the prices producers paid for $\mathrm{N}$-fertilisers in October 2000 as determined by our farm survey. Second-order conditions for a maximum were satisfied in all cases. According to the Mitscherlich function, the profit-maximising dose in maize production is $171.7 \mathrm{~kg} \mathrm{~N} \mathrm{ha}^{-1}$ and the corresponding yield level would be $8904 \mathrm{~kg}$ maize ha ${ }^{-1}$. Enforcing an $\mathrm{N}$-fertiliser tax of $100 \%$, or a product tax of $50 \%$ would reduce the profit-maximising dose by approximately $98 \mathrm{~kg} \mathrm{~N} \mathrm{ha}^{-1}$. If such a tax were to be implemented, the yield level would fall by $1434 \mathrm{~kg}$ $\mathrm{ha}^{-1}$, and the gross margin would fall by EUR 43 ha $^{-1}$.

\section{Do farmers exceed profit-maximising levels of $\mathrm{N}$-fertilisation?}

Farmers in the surveyed sample used $\mathrm{N}$-fertiliser doses of 206-230 kg N ha-1 when the manure employed was taken into account. In other words, the Croatian farmers in this sample appear to use higher-than-optimal levels of $\mathrm{N}$ when the $\mathrm{N}$ contributed by manure is taken into account. If only the $\mathrm{N}$ in artificial fertilisers is counted, farmers used an $\mathrm{N}$ input $\left(161 \mathrm{~kg} \mathrm{~N} \mathrm{ha}^{-1}\right)$ close to the optimal level. Could farmers possibly increase their profits by lowering levels of $\mathrm{N}$ intensity? This is not necessarily the case. One possible explanation for the higher-than-optimal $\mathrm{N}$-input is that the technology used by farmers when spreading manure does not allow them to use the $\mathrm{N}$-input of manure in an efficient manner. Only a part of the manure's $\mathrm{N}$-content will

Table 3. Alternative functional forms of the N-response curve for maize, corresponding profit-maximising fertiliser doses, levels of yield, and the impact of a $100 \%$ fertiliser tax or $50 \%$ product tax on fertiliser dosage.

\begin{tabular}{|c|c|c|c|c|c|}
\hline Functional form & First-order condition & $\begin{array}{l}\text { Profit } \\
\text { maximising } \\
\text { fertiliser } \\
\text { doses, } \mathrm{kg} \mathrm{ha}^{-1}\end{array}$ & Yield, kg ha ${ }^{-1}$ & $\begin{array}{l}\text { Return after } \\
\text { subtraction of } \\
\text { fertiliser cost, } \\
\text { euro } \mathrm{kg}^{-1} \mathrm{ha}^{-1}\end{array}$ & $\begin{array}{l}\text { Profit maximising fertiliser } \\
\text { doses, } \mathrm{kg} \mathrm{ha}^{-1} \text { with } 100 \% \\
\text { N-fertiliser tax or } 50 \% \\
\text { product-price tax }\end{array}$ \\
\hline $\begin{array}{l}\text { Quadratic } \\
y=\beta_{0}+\beta_{1} x+\beta_{2} x_{2}\end{array}$ & $x^{*}=\frac{\frac{w}{p}-\beta_{1}}{2 \beta_{2}}$ & 185.0 & 9,130 & 715 & 86 \\
\hline $\begin{array}{l}\text { Square root } \\
y=\beta_{0}+\beta_{1} x^{1 / 2}+\beta_{2} x\end{array}$ & $x^{*}=\left[\frac{\frac{w}{p}-\beta_{2}}{\frac{\beta_{1}}{2}}\right]$ & 145.3 & 8,565 & 700 & 39 \\
\hline $\begin{array}{l}\text { Mitcherlich } \\
y=m\left(1-k e^{-\beta x}\right)\end{array}$ & $x^{*}=\frac{\ln \left(\frac{p m k \beta}{w}\right)}{\beta}$ & 171.7 & 8,904 & 707 & 74 \\
\hline
\end{tabular}


Vol. 14 (2005): 293-309.

actually be available to the plant when the need for it is at a maximum. If this is the case, a rational farmer will base his fertilising decision on the $\mathrm{N}$ input achieved using artificial fertilisers. In other words, when estimating profit-maximising doses on the basis of what is possible in N-response experiments, farmers appear to be optimising their $\mathrm{N}$-input. On the other hand, the yield level achievable at the profit-maximising intensity level in experimental conditions is considerably higher (3100$3800 \mathrm{~kg} \mathrm{ha}^{-1}$ ) than the maize yields actually achieved on farms. As the use of $\mathrm{N}$-fertilisers and manure on the studied farms does not result in adequate yields, it would appear that factors other than nutrient input are restricting yields. Given these low yields, farmers are not optimising either $\mathrm{N}$-fertilisation or cropping practices. One consequence is that farmers could choose between two options to increase their profits: 1) Attempt to influence the growth factors that restrict yields, thereby utilising the $\mathrm{N}$ input of both artificial fertilizers and manure more efficiently; or 2) Reduce levels of nutrient intensity. From an environmental point of view, both options would make good sense. While changing the functional form to a quadratic or a square-root form changes the optimal $\mathrm{N}$-fertiliser doses and corresponding yields to some extent, the conclusions drawn remain unchanged.

\section{Effluent production function}

The effluent-production function (leakage function) was estimated in both its unrestricted (12) and restricted form (13). The restrictions of (13) were tested. It was found that the null hypothesis of the dummies being zero $\left(H_{0}=\delta_{1}=\delta_{2}=\delta_{3}=0\right)$ could not be rejected using either the F-test or on the basis of the log-likelihood ratio. The estimated leakage function should not therefore include dummies. The estimation result for the $\mathrm{NO}_{3}-\mathrm{N}$-leakage function according to (13) is presented in the lower part of Table 2.

All the estimated coefficients are highly significant (significance level of $\mathrm{P}<0.01$ or $\mathrm{P}<0.001$ ). The adjusted coefficient of determination (0.68) indicates that goodness of fit of the leakage func-

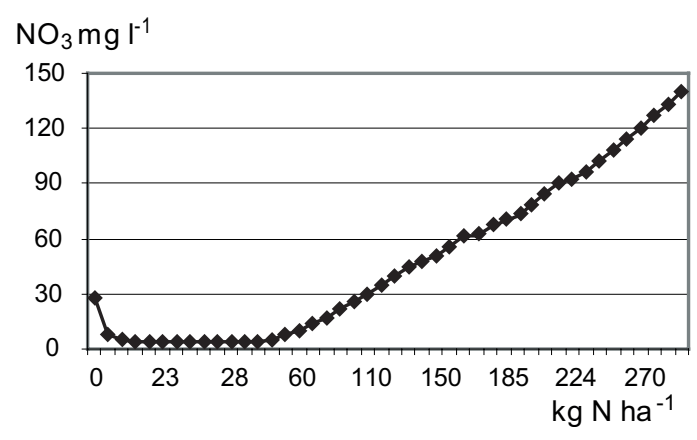

Fig. 1. Estimated restricted leaching function, leached $\mathrm{NO}_{3} \mathrm{mg} \mathrm{l}^{-1}$. $\mathrm{NO}_{3}-\mathrm{N}$ leakage has been converted into $\mathrm{NO}_{3}$ leakage using the conversion factor 4.427.

tion was rather good, given that the data was pooled. The assumption of homoscedastic errors could not be rejected on the basis of the White test. The estimated restricted leaching function is presented in Figure 1.

It is interesting that $\mathrm{NO}_{3}$-leaching initially appears to fall. This phenomenon can be attributed to the fact that a growing crop takes up more nutrients than a weak crop. A small amount of fertiliser will therefore reduce leaching because of the increase in crop growth. As a consequence, $\mathrm{NO}_{3}$ leaching initially falls, reaching its lowest limit at a fertiliser input of $26 \mathrm{~kg} \mathrm{~N} \mathrm{ha}^{-1}$. At the profit-maximising level of fertiliser intensity $(171.7 \mathrm{~kg} \mathrm{~N}$ $\mathrm{ha}^{-1}$ ) the amount of leached $\mathrm{NO}_{3}$ is estimated to be $62.11 \mathrm{mg} \mathrm{NO}_{3} \mathrm{1}^{-1}$. This is an amount exceeding the critical level stipulated by the Nitrate Directive (50 mg NO $\mathrm{N}_{3} 1^{-1}$ ). The claim that $\mathrm{NO}_{3}$-levels in groundwater are critically high in some areas in Croatia is supported by this estimate (Romic et al. 1997, Tomic et al. 1997, Simunic et al. 1998, Klacic et al. 1999).

Altering the functional form of the N-response function for maize results in slight changes to the values for leached $\mathrm{NO}_{3}$. The profit-maximising doses indicated by the square-root form changed the value for $\mathrm{NO}_{3}$-leaching to $47.8 \mathrm{mg} \mathrm{NO}_{3} \mathrm{l}^{-1}$ and the corresponding doses for the quadratic form resulted in $\mathrm{NO}_{3}$-leakage of $69.6 \mathrm{mg} \mathrm{NO}_{3} \mathrm{l}^{-1}$. 
Sumelius, J. et al. Marginal abatement costs for reducing leaching of nitrates in agriculture

\section{Total and marginal abatement costs}

The estimated total abatement costs for a given level of $\mathrm{NO}_{3}$ reduction through the financial incentive $k$ are shown in Table 4. Conversion of $\mathrm{NO}_{3}-\mathrm{N}$ to $\mathrm{NO}_{3}$ is achieved by multiplying the former by a conversion factor of 4.427 . The $\mathrm{N}$-response curve for yields is based on the Mitscherlich specification.

A $100 \% \mathrm{~N}$-tax or a $50 \%$ product tax will lead to $\mathrm{NO}_{3}$-leaching being reduced to $47.16 \mathrm{mg} \mathrm{NO}$ $\mathrm{l}^{-1}$. Noteworthy is the fact that the total abatement cost for an $\mathrm{N}$-fertiliser tax would be EUR -0.649 $\left(\mathrm{mg} \mathrm{NO} \mathrm{N}^{-1}\right)^{-1}$, indicating a net return to society. This means a fertiliser tax would generate a net social benefit even when the value of the resulting environmental improvement is not taken into account. An N-tax of $50 \%$ could be introduced, the tax revenue could be directed back to farmers and society would still be better off. For the product tax and for the N-quota, the total abatement cost would be EUR $0.921\left(\mathrm{mg} \mathrm{NO}_{3} \mathrm{l}^{-1}\right)^{-1}$ indicating a real cost. The $\mathrm{N}$-tax appears to have a lower total abatement cost for society than either the $\mathrm{N}$-quota or the product tax. The product tax and the N-quota are equally efficient (assuming no costs for monitoring or information). The relative efficiency of these two instruments therefore depend on factors that lie outside this analysis. While the order of these instruments is hardly surprising, the magnitude of the difference is, however, quite significant. Ordering of the instruments is not dependent upon specification of the N-response function.

It may be noted that direct comparison between the abatement costs for a fertiliser tax that are reported in this study and estimates by Lankoski and
Ollikainen (1999) and Vatn et al. (1997) is difficult. The reason is that those studies reported the costs of reduced leaching as an amount of money per area unit while the measure used in the present study is an amount of money per concentration. A reliable comparison of leaching in terms of $\mathrm{N} \mathrm{kg}$ $\mathrm{ha}^{-1}$ would require data on water leachate amounts for every particular outflow.

To establish how large reductions in N-fertilisers should be achieved through $\mathrm{N}$-taxes before considering other measure, the MAC of the N-tax must be examined. Figure 2 illustrates the MAC for various levels of $\mathrm{N}$-taxes and the consequent marginal reduction in $\mathrm{NO}_{3}$-leaching.

The figure shows that MAC are non-constant, which suggests that small reductions in fertilisation rates result in small MAC while large reductions give rise to higher MAC. In fact, MAC are actually negative up to an $\mathrm{N}$-tax level of approximately $60 \%$, indicating no costs to society up to this level (although the gross margins of farmers are reduced, i.e. the income distribution will change as a result). At $\mathrm{N}$-tax levels above $100 \%$, MAC appear to increase rapidly while $\mathrm{NO}_{3} 1^{-1}$ leaching falls at a diminishing rate. The MAC implied by a product tax and an N-quota show a similar increasing trend although they, contrary to the N-tax, remain positive at small abatement levels. An N-tax of $60 \%$ corresponds to a profit-maximizing fertilization level of approximately $105 \mathrm{~kg}$ $\mathrm{N} \mathrm{ha}^{-1}$. The fact that an $\mathrm{N}$-tax of $60 \%$ yields a social return indicates that reductions in fertilisation implemented through $\mathrm{N}$-taxes should be achieved to this level before social planners should consider other measures (such as support for catch crops, buffer strips or catchment dams).

Table 4. Abatement cost of economic instruments for a 50\% N-tax, a $100 \%$ product-price tax or an N-quota.

\begin{tabular}{lccc}
\hline & N-fertiliser tax & Product tax & N-Quota \\
\hline Reduction in leaching $\left(\mathrm{mg} \mathrm{NO}_{3} \mathrm{l}^{-1}\right)$ & 47.16 & 47.16 & 47.16 \\
Abatement cost $\left(€ / \mathrm{mg} \mathrm{NO}_{3} \mathrm{l}^{-1}\right)$ & -0.649 & 0.921 & 0.921 \\
Reduction in private gross margin $\left(€ \mathrm{ha}^{-1}\right)$ & 117.44 & 412.06 & 43.42 \\
Reduction in private gross margin $\left(€ / \mathrm{mg} \mathrm{NO}_{3} \mathrm{l}^{-1}\right)$ & 2.49 & 8.74 & 0.921 \\
New leaching level $\left(\mathrm{mg} \mathrm{NO}_{3} \mathrm{l}^{-1}\right)$ & 14.95 & 14.95 & 14.95 \\
\hline
\end{tabular}


$\mathrm{MAC}, € / \mathrm{mg} \mathrm{NO}_{3} \Gamma^{-1}$

Reduction in leaching $\mathrm{mg} \mathrm{NO}_{3} \Gamma^{-1}$

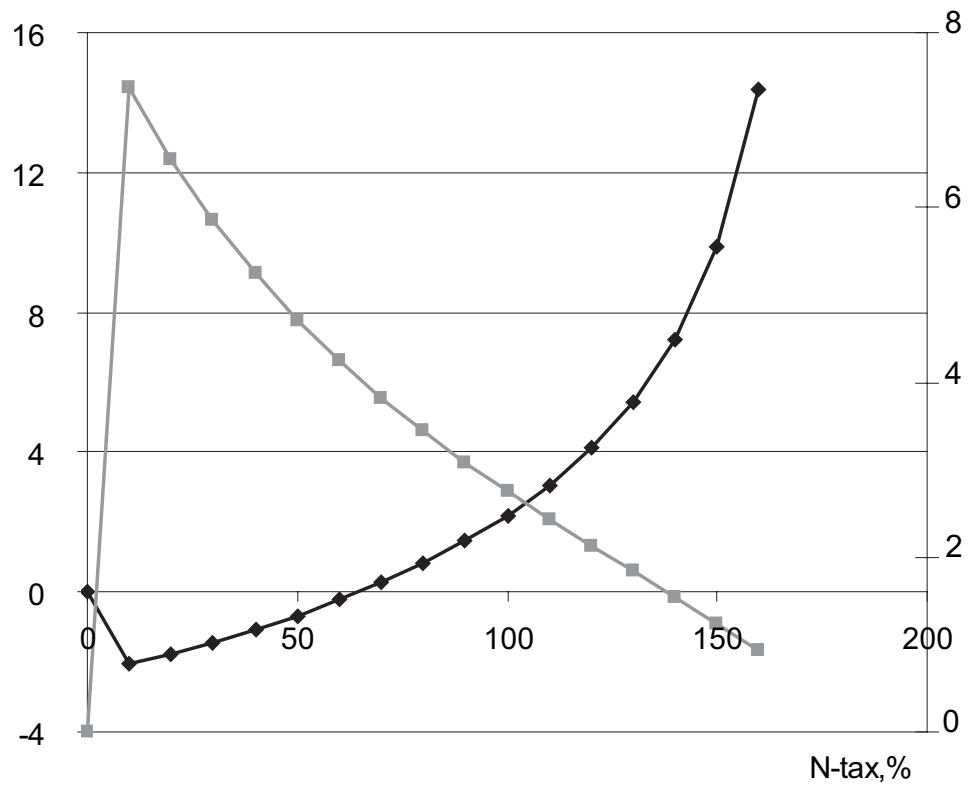

$\mathrm{MAC}, € / \mathrm{mg} \mathrm{NO}_{3} I^{-1} \rightarrow-$ Reduction in leaching, $\mathrm{mg} \mathrm{NO}_{3} \mathrm{I}^{-1}$
For levels of total reduction below $50 \mathrm{mg} \mathrm{NO}$ $\mathrm{l}^{-1}$, MAC for the $\mathrm{N}$-tax are smaller than for both the product tax and the N-quota. For levels of total reduction below $20 \mathrm{mg} \mathrm{NO}_{3} \mathrm{l}^{-1}$, MAC for the N-quota are lower than MAC for the product tax. However, if $\mathrm{NO}_{3}$-leaching is reduced more than $20 \mathrm{mg}$ $\mathrm{NO}_{3} \mathrm{l}^{-1}$, the order changes: the product tax has higher MAC than the $\mathrm{N}$-quota for levels of $\mathrm{NO}_{3}$ leaching reduction higher than this.

\section{Conclusions}

When using the prices for maize and $\mathrm{N}$ obtained in the sample, profit-maximising levels of fertilisation in maize production were estimated to be in the range $145-185 \mathrm{~kg} \mathrm{~N}^{-1}$ depending upon specification of the crop response. Using the theoreti- cally-superior functional form leads to profit-maximising $\mathrm{N}$-doses of approximately $171.7 \mathrm{~kg} \mathrm{~N}^{-1}$. Corresponding $\mathrm{NO}_{3}$-levels in waters were estimated to be $62 \mathrm{mg} \mathrm{NO}_{3} \mathrm{l}^{-1}$ at this level of fertiliser intensity. This $\mathrm{NO}_{3}$-level is above the critical level stipulated by the Nitrate Directive $\left(50 \mathrm{mg} \mathrm{NO}_{3} \mathrm{l}^{-1}\right)$. The average $\mathrm{N}$ applied as mineral fertiliser by farmers in the sample, $161 \mathrm{~kg} \mathrm{~N} \mathrm{ha}^{-1}$, was close to the estimated profit-maximising N-dose. Corresponding $\mathrm{NO}_{3}$ levels in the water is estimated to be $56 \mathrm{mg} \mathrm{NO}_{3} \mathrm{l}^{-1}$, or slightly above what the Nitrate Directive defines as the critical maximum level. If account is taken of the $\mathrm{N}$-content in manure which farmers apply to their fields, the total $\mathrm{N}$-dose actually applied increases to $206-230 \mathrm{~kg} \mathrm{~N} \mathrm{ha}^{-1}$ depending upon the farm. The corresponding estimate for the $\mathrm{NO}_{3} \mathrm{l}^{-1}$ level in groundwater is then in the range 82-96 mg NO${ }_{3} \mathrm{l}^{-1}$, or some 1.6-1.9 times higher than the critical maximum level defined in the Nitrate Directive. 
The possible yield level obtained in experimental conditions at profit-maximising $\mathrm{N}$-intensity levels was estimated to be $8904 \mathrm{~kg}$ maize ha-1, 3100-3800 $\mathrm{kg} \mathrm{ha}^{-1}$ higher than levels recorded on the farms in the sample. The use of mineral fertilisers and manure on the sample farms does not therefore currently appear to lead to adequate yields. The excess nutrients are susceptible to leaching, placing an unnecessary burden both the surface and underground waters in the area which may have extensive long-term effects. To increase their profits, farmers have two options: 1 Attempt to influence growth factors that are restricting yields, thereby utilising the $\mathrm{N}$-input of both artificial fertilizers and manure more efficiently, 2. Reduce levels of nutrient intensity. Both actions would reduce $\mathrm{NO}_{3}$-leaching.

One way of attempting to influence $\mathrm{NO}_{3}$-leaching is by the application of economic instruments which reduce it. In this study, three economic instruments for reducing $\mathrm{NO}_{3}$-leaching were analysed: a fertiliser tax, a product tax and a fertiliser quota corresponding to both of these taxes. A 100\% $\mathrm{N}$-tax or a $50 \%$ product tax would reduce profitmaximising $\mathrm{N}$-doses to approximately $74 \mathrm{~kg} \mathrm{~N}$ $\mathrm{ha}^{-1}$ (a reduction of $98 \mathrm{~kg} \mathrm{ha}^{-1}$ ), and should reduce $\mathrm{NO}_{3}$ levels from $62.11 \mathrm{mg} \mathrm{NO}_{3} \mathrm{l}^{-1}$ to $14.95 \mathrm{mg} \mathrm{NO}_{3}$ $\mathrm{l}^{-1}$ ). This is a leaching reduction of $47.16 \mathrm{mg} \mathrm{NO}_{3}$ $\mathrm{l}^{-1}$ (i.e. $76 \%$ ). At this abatement level the $\mathrm{N}$-tax has the lowest total abatement cost, EUR -0.649 (mg $\left.\mathrm{NO}_{3} \mathrm{l}^{-1}\right)^{-1}$ and indicates a net social return. Both a product tax and an $\mathrm{N}$-quota would have a high abatement cost of EUR $\left.0.921\left(\mathrm{mg} \mathrm{NO}_{3} \mathrm{l}^{-1}\right)^{-1}\right)$.

The estimated MAC for all the instruments are non-constant and increase at a growing rate. MAC for $\mathrm{N}$-taxes are positive for $\mathrm{N}$-taxes lower than $60 \%$, indicating a net return to society without taking into account improvement in water quality. This implies that an $\mathrm{N}$-tax of up to $60 \%$ provides a social return and indicates that reduction rates in fertilisation up to this level should be accomplished before considering governmental support for other measures (such as catch crops, buffer strips or catchment dams).

MAC for the N-tax are smaller than they are for both the product tax and the N-quota in the relevant range of $\mathrm{NO}_{3}$-leaching reduction. While
MAC for the N-quota are lower than MAC for the product tax when total reduction levels are below $20 \mathrm{mg} \mathrm{NO}_{3} \mathrm{l}^{-1}$, for reduction levels above this the order of the two instruments is reversed.

Since yields in Croatia are relatively modest, other crop-husbandry practices than $\mathrm{N}$-fertilisation may be constraining factors as regards yield increase. If these factors could be identified, an economically-optimal level of yield corresponding to the actual use of $\mathrm{N}$ might be accomplished, and $\mathrm{NO}_{3}$-leaching would be correspondingly reduced. It is quite likely that the technology used by farmers is not as efficient as the technology used in the field trials, and in spite of using profit-maximising $\mathrm{N}$-fertiliser doses, farmers will not reach adequate levels of yield in maize production. What are these limiting factors? They should be sought in elements connected with soil cultivation, crop protection and crop rotation. It would probably be fairly easy to identify some measures which could be implemented in a relatively-short time period. Such measures encompass a large range of factors: rational technology and the current incentives for their use in production, fertilisation and liming based on soil analysis, improvement in the soiltillage system, changes in crop rotation with a higher proportion of leguminous plants, proper drainage, change in the system of support for producers and applying adequate technological procedures in harmony with appropriate soil management. Other measures will take longer. Long-term changes should focus on determination of the basic indicators for soil sustainability in the area, as well as on the determination of true production capacities, and a favourable allocation of production according to the principles of soil sustainability. If these agronomic principles were to be applied in practice (e.g. by cross-compliance stipulating the use of good agricultural practices), current N-levels would be utilised in a more rational manner.

Finally, from the agronomic point of view it is essential to educate farmers about the vital importance of fertilisation which is based on adequate soil analysis. Research activities should be oriented toward a detailed determination of the basic indicators for soil sustainability in this area, and determination of true production capacities should be 
Vol. 14 (2005): 293-309.

harmonised with the requirements of sustainable soil management. Results obtained in detailed research over extended periods suggest there is a need to create a computer model which incorporates contemporary science, professional practice, and methodology, in order to determine the impact of agricultural production on both surface water and groundwater. Such a model should also result in a favourable allocation of production for the utilisation of the area on soil sustainability-principles and also contribute to maintaining population levels in this rural location.

Acknowledgements. The authors are grateful for valuable suggestions regarding this paper from two anonymous referees as well as for helpful comments from Stefan Bäckman, Markku Ollikainen and Timo Sipiläinen (University of Helsinki). Work on which this paper is based was carried out within the EU's CEESA project QLK5-199901611, Fifth Framework Programme in cooperation with FAO Sub regional Office for Central and Eastern Europe.

\section{References}

Andréasson, I.-M. 1990. Costs for reducing farmers' use of nitrogen in Gotland, Sweden. Ecological Economics 2: 287-299.

Bäckman, S., Vermeulen, S. \& Taavitsainen, V.-M. Longterm fertilizer field trials: comparison of three mathematical response models. Agricultural and Food Science in Finland 6: 151-160.

Bakken, L. \& Romstad, E. 1992. Avlingskurver og variasjon - nye perspektiver. In: Avlingskurver. Økonomiske og naturvitenskaplige perspektiver. Report from Department of Economy and Social Sciences, Norwegian Agricultural University, Ås. p. 91-107.

Baumol, W.J. \& Oates, W.E. 1988. The theory of environmental policy. 2nd ed. USA: Cambridge University Press. 296 p.

Bijl, G. van der, Zeijts, H. van \& Knickel, K. 1999. Nitrogen problems and current policies. In: Zeijts, H. van (ed.). Economic instruments for nitrogen control in European agriculture. Utrecht, Netherlands: CLM. p. 5-26.

Bleken, M.A. \& Bakken, L.R. 1997. The anthropogenic nitrogen cycle in Norway. In: Romstad, E. et al. (eds.). Controlling mineral emissions in European agriculture. Economics, policies and the environment. UK: CAB international. p. 27-40.

Braden, J.B \& Segerson, K. 1993. Information problems in the design of nonpoint sources pollution policy. In: Russell, C.S. \& Shogren (eds.). Theory, modeling and expe- rience in the management of nonpoint source pollution. Boston, USA: Kluwer Academic Publishers. p. 1-36.

Brouwer, F. \& Hellegers, P. 1997. Nitrogen flows at farm level across European Union agriculture. In: Romstad, E. et al. (eds.). Controlling mineral emissions in European agriculture. Economics, policies and the environment. UK: CAB international. p. 11-26.

De Clercq, Gertsis, A.C., Hofman, G., Jarvis, S.C., Neeteson, J.J. \& Sinabell, F. (eds.). 2001. Nutrient management legislation in European countries. Netherlands: Wageningen Pres. 340 p.

Directive 91/676/EEC. Council Directive of 12 December 1991 concerning the protection of waters against pollution caused by nitrates from agricultural sources.

Gabel, H.L. \& Sinclair-Desgagné, B. 2000. The firm its procedures and win-win environmental regulations. In: Frontiers of environmental economics. UK: Edward Elgars p. 148-175.

Goodchild, R.G. 1998. EU policies for the reduction of nitrogen in water: the example of the Nitrates Directive. Environmental pollution 102, S1: 737-740.

Granstedt, A. 2000. Increasing the efficiency of plant nutrient recycling within the agricultural system as a way of reducing the load to the environment - experience from Sweden and Finland. Agriculture, Ecosystems and Environment 1570: 1-17.

Gren, I.-M., Elofsson, K. \& Jannike, P. 1997. Cost-effective nutrient reduction to the Baltic Sea. Environmental and Resource Economics 10: 341-362.

Grgić, Z. \& Mesić, M. 2001. Analysis of environmental impact of farming systems in Lonja field, Croatia. In: Bäckman, S. et al. (eds.). Analysis of environmental impact of farming systems in five Central and Eastern European countries. D7 Report of the Central and Eastern Sustainable Agriculture (CEESA), Project submitted to the EU Commission. Helsinki, University of Helsinki. p. 37-49.

Griffin, R.L. \& Bromley, D.W. 1982. Agricultural runoff as a nonpoint externality: a theoretical development. American Journal of Agricultural Economics 64, 3: 547-552.

Hanley, N. 1990. The economics of nitrate pollution. European Review of Agricultural Economics 17, 2: 129-151.

Hanley, N. 2001. Policy on agricultural pollution in the European Union. In: Shortle, J.S. \& Abler, D. (eds.). Environmental policies for agricultural pollution control. UK: CABI Publishing. p. 151-162.

Horan, R.D. \& Shortle, J.S. 2001. Environmental instruments for agriculture. In: Shortle, J.S. \& Abler, D. (eds.). Environmental policies for agricultural pollution control. UK: CABI Publishing. p. 19-65.

ISSS 1994. International Society of Soil Science, ISRIC International Soil Reference and Information Centre, FAO Food and Agriculture Organization of the United Nations, 1994. World Reference Base for Soil Resources, Draft. Wageningen/Rome.

Jansson, B.-0. 1997. The Baltic Sea: current and future status and impact of agriculture. Ambio 26, 7: 424-431.

Klacic, Z., Petosic, D. \&Coga, L. 1999. Nitrate leaching in different pipe drainage distances, Agriculturae Conspectus Scientificus 63, Supplement 4: 331-338.

Lankoski, J. 2000. The cost-effectiveness of agri-environmental policy mixes in reducing nutrient runoffs. Licen- 
Sumelius, J. et al. Marginal abatement costs for reducing leaching of nitrates in agriculture

tiate thesis. Agricultural Economics Research Institute. $49 \mathrm{p}$.

Lankoski, J. 2003. The environmental dimension of multifunctionality: economic analysis and implications for policy design. MTT Agrifood Research Finland. Agrifood Research reports 20. 107 p. (Doctoral dissertation).

Lankoski, J. \& Ollikainen, M. 1999. The environmental effectiveness of alternative agri-environmental policy reforms: theoretical and empirical analysis. Agricultural and Food Science in Finland 8: 321-331.

Mesić, M., Butorac, A., Basic, F., Gaspar, I. \& Kisic, I. 1997. Influence of mineral nitrogen rates on nitrate leaching from drained pseudogley. In: 7th Gumpensteiner Lysimetertagung. Lysimeter und nachhaltige Landnutzung, Bal Gumpenstein, Austria. p. 169-170.

Mesic, M., Butorac, A., Basic, F., Kisic, I. \& Gaspar, I. 2000. Influence of black fallow on nitrate leaching. In: Proceedings of 15th ISTRO Conference. Fort Worth, Dallas, USA. p. 7.

Paris, Q. 1992a. The return of von Liebig's "Law of the minimum". Agronomy Journal 84, 6: 1040-1046.

Paris, Q. 1992b. The von Liebig hypothesis. American Journal of Agricultural Economics 474, 4: 1019-1028.

Ribaudo, M. 2001. Non-point source pollution control policy in the USA. In: Shortle, J.S. \& Abler, D. (eds.). Environmental policies for agricultural pollution control. UK: CABI Publishing. p. 123-149.

Ribaudo, M. \& Shortle, J.S. 2001. Estimating benefits and costs of pollution control policies. In: Shortle, J.S. \& Abler, D. (eds.). Environmental policies for agricultural pollution control. UK: CABI Publishing. p. 85-122.

Rougoor, C.W., Zeijts, H. van, Hofreiter, M.F. \& Bäckman, S. 2001. Experiences with fertilizer taxes in Europe. Journal of Environmental Planning and Management 44, 6: 877-887.

Romic, D., Romic, M., Klacic, Z., Petosic, D. \& Stricevic, I. 1997. Effect of land use upon the leaching of nitrogen into groundwater in the area of the future water pumping station. In: Gumpensteiner Lysimetertagung. Lysimeter und Nachhaltige Landnutzung Bal Gumpenstein, Austria.

Shortle, J.S. 1996. Economic incentives for nutrient pollution reduction. In: Weersink, A. \& Livernois, J. (eds.). Exploring alternatives. Potential application of economic instruments to address selected environmental problems in Canadian agriculture. Canada: Environmental Bureau, Agriculture and Agri-food Canada. p. 47-76.

Shortle, J.S. \& Abler, D.G. 1997. Nonpoint pollution. In: Folmer, H. et al. (eds.). The international yearbook of environmental and resource economics 1997/1998. A survey of current issues. p. 114-155.

Shortle, J.S., Abler, D.G.\& Ribaudo, M. 2001. Agriculture and water quality: the issues. In: Shortle, J.S. \& Abler, D. (eds.). Environmental policies for agricultural pollution control. UK: CABI Publishing. p. 1-18.

Simmelsgaard, S.E. 1991. Estimering af funktioner for kvælstofudvaskning. Kvælstofudvaskning som funktion af kvælstoftilførsel for forskellige afgrøder dyrket på sandjord og lerjord. In: Rude, S. (ed.). Kvælstofgødning i landbruget - behov og udvaskning nu og i fremtiden.
Copenhagen. Institute of Agricultural Economics. Report 62. p. 135-150.

Simmelsgaard, S.E. \& Djurhuus, J. 1998. An empirical model for estimating nitrate leaching as affected by crop type and long-term $\mathrm{N}$ fertilizer rate. Soil Use and Management 14: 37-43.

Simunic, I., Tomic, F. \& Klacic, Z. 1998. Djelovanje drenazi na koncentraciju dusika u drenaznoj vodi. Hrvatske vode 1. p. 107-110.

Sumelius, J. 1993. A response analysis of wheat and barley to nitrogen in Finland. Agricultural Science in Finland 2: 465-480.

Sumelius, J. 1994. Controlling nonpoint source pollution of nitrogen from agriculture through economic instruments in Finland. Agricultural Economics Research Institute publications 74 .

Tauer, L.W. 1995. Do New York dairy farmers maximize profits or minimize costs? American Journal of Agricultural Economics 77, May 1995: 421-429.

Toma, L. 2002. Farming systems and rural community welfare from an environmental perspective. A case study on agricultural nonpoint source pollution in Romania. In: Pre-proceedings of the Fifth IFSA European Symposium, Farming and Rural Systems Research and Extension, Florence, Italy: Università degli Studi di Firenze, Facolta di Agraria. p. 408-417.

Tomic, F., Simunic, I., Petosic, D., Stricevic, I. \& Klacic, Z. 1997. Utjecaj cijevne drenaze na ispiranje dusika iz tla. 4. strucna sjednica Radne skupine "Zastita tla" Podunavskih zemalja, Osijek.

Varian, H. 1992. Microeconomic analysis. 3rd ed. USA. $506 \mathrm{p}$.

Vatn, A., Bakken, L.R., Bleken, M.A., Botterweg, P., Lundeby, H., Romstad, E., Rørstad, P.K. \& Vold, A. 1996. Policies for reduced nutrient losses and erosion from Norwegian agriculture. Norwegian Journal of Agricultural Sciences Supplement 23. 319 p.

Vatn, A., Bakken, L.R., Lundeby, H., Romstad, E., Rørstad, P.K. \& Vold, A. 1997. Regulating nonpoint source pollution from agriculture: An integrated modelling analysis. European Review of Agricultural Economics 24: 207229.

Weinberg, M. 1991. Economic incentives for the control of agricultural non-point source water pollution. Department of Agricultural Economics, U.C. Davis. 259 p. (Unpublished dissertation).

Yadav, S.N, Peterson, W. \& Easter, W. 1996. Do farmers overuse nitrogen fertilizer to the detriment of the environment? Environmental and Resource Economics 9: 323-340.

Zellei, A. 2001. Challenges for agri-environmental policies in CEE countries. CEESA discussion paper No $3 / 6 / 2001$. Humboldt University of Berlin, Chair of Resource Economics, Berlin. $34 \mathrm{p}$.

Zellei, A., Gorton, M. \& Lowe, P. 2002. A comparative analysis of the Polish, Lithuanian and Slovakian case studies on the implementation of the Nitrate Directive. In: Zellei, A. et al. (eds.). Alternative concepts of agri-environmental policies in Central and Eastern European countries. Report of the Central and Eastern Sustainable Agriculture (CEESA). University of Newcastle, Newcastle. p. 59-76. 


\title{
SELOSTUS
}

\section{Nitraattihuuhtouman vähentämisen rajakustannus Kroatian maataloudessa}

\author{
John Sumelius, Milan Mesić, Zoran Grgić, Ivica Kisic ja Ramona Franić \\ Helsingin yliopisto ja Zagrebin yliopisto
}

\begin{abstract}
Artikkelissa analysoidaan nitraattitypen vähentämiseen tähtäävien vero-ohjauskeinojen rajakustannus, tietyn nitraattipitoisuuden vähentämisen kokonaiskustannus ja veron vaikutuksia $\mathrm{NO}_{3}$-huuhtoumaan Kroatian maataloudessa. Analysoitavana on $50 \%$ typpivero, $100 \%$ tuotevero ja tätä huuhtoumaa vastaava typpikiintiö tilatasolla. Typpihuuhtouman vähentämisen rajakustannus tuottaa tietoa siitä, kuinka paljon typpilannoituksen intensiteettiä tulisi vähentää mainituilla keinoilla ennen kuin muut toimenpiteet (esim. ympäristötuki suojakaistoille, kosteikoille tai välikasvustolle) tulisivat kyseeseen.

Maissin typpilannoituskokeiden perusteella estimoitiin kolme tuotantofunktiota ja johdettiin vastaava voittoa maksimoiva typpilannoitustaso. Lysimetriveden $\mathrm{NO}_{3}-\mathrm{N}$ pitoisuuksien perusteella estimoitiin $\mathrm{NO}_{3}-\mathrm{N}$ huuhtoumafunktio. Estimoitua voittoa maksimoivaa typpilannoitustasoa verrattiin otokseen, joka käsitti 20 perheviljelmää. Otoksesta laskettiin hehtaarikohtainen käytetyn typen määrä väkilannoitteissa ja lannassa. Tilojen maksamia typpilannoitehintoja ja saatuja maissin tuottajahintoja käytettiin voittoa maksimoivan typpilannoitustason määrittämiseksi. Lopuksi estimoitiin voittoa maksimoivaa lannoitustasoa $(171,7 \mathrm{~kg} / \mathrm{ha})$ vastaava $\mathrm{NO}_{3}$-pitoisuus, tilojen nykykäytännön mukainen $\mathrm{NO}_{3}$ pitoisuus sekä typpiveron, tuoteveron ja lannoitekiintiön voittoa maksimoivan lannoitustason vastaavat $\mathrm{NO}_{3}$-pitoisuudet.
\end{abstract}

Tulokset viittaavat siihen, että otoksen viljelijät käyttävät enemmän typpeä kuin voittoa maksimoiva taso edellyttäisi, mikäli lannan typpi otetaan huomioon (206-230 N kg/ha). Mikäli lannan typpeä ei oteta huomioon, viljelijät lannoittavat jonkin verran alle voittoa maksimoivan typpilannoitustason (160,6 N kg/ha). Viljelijöiden käyttämät typpiravinteet ml. lannan typpi johtaa estimoituihin pohjaveden $\mathrm{NO}_{3}$-pitoisuuksiin, jotka ovat 162-192\% korkeampia kuin nitraattidirektiivin edellyttämä kriittinen taso, $50 \mathrm{mg} / 1 \mathrm{NO}_{3}$. Voittoa maksimoivalla typpitasolla $\mathrm{NO}_{3}$-pitoisuus estimoitiin tasolle $62 \mathrm{mg} / \mathrm{l} \mathrm{NO}_{3}$. Typpikiintiön nitraattihuuhtouman vähentämisen rajakustannus oli negatiivinen $(-0.649 \mathrm{euro} / \mathrm{mg} /$ $1 \mathrm{NO}_{3}$ ), mikä viittaa siihen, että vero tuottaa positiivisen nettotulon jo ilman ympäristöhyötyjen ottamista huomioon. Vasta yli $60 \%$ typpiveroa vastaava vähentämiskustannus muuttuu negatiiviseksi. Lannoitusintensiteetti tällä tasolla on $105 \mathrm{~kg} / \mathrm{ha}$ typpeä. Vasta alhaisimmilla lannoitustasoilla kannattaisi harkita vaihtoehtoisia toimenpiteitä (esim. ympäristötukea suojakaistoille, kasvipeitteisyydelle tai kosteikoille). Mainittujen verokeinojen rajavähentämiskustannus ei ole vakio ja se kasvaa kiihtyvästi.

Typpiverolla saavutetun $\mathrm{NO}_{3}$-vähentämisen rajakustannus on alhaisin, mikäli nitraattityppeä ei vähennetä enempää kuin $50 \mathrm{mg} / 1 \mathrm{NO}_{3}$. Typpikiintiöllä saavutetun $\mathrm{NO}_{3}$-vähentämisen rajakustannus on alhaisempi kuin tuoteverolla saavutetun $\mathrm{NO}_{3}$-vähentämisen rajakustannus vähentämisen tasoilla alle $20 \mathrm{mg} / \mathrm{l} \mathrm{NO}$, mutta korkeampi kuin tuoteveron rajakustannus korkeimmilla vähentämisen tasoilla. Viljelijöiden satotaso on lisäksi $3100-3800 \mathrm{~kg} / \mathrm{ha}$ alhaisempi kuin olisi mahdollista tällä lannoitustasolla. Viljelijöiden olisi mahdollista nostaa nettotulojaan joko vaikuttamalla muihin kuin lannoitusta rajoittaviin kasvutekijöihin tai pienentämällä lannoitepanosta. 
